\title{
URINARY EXCRETION OF AMINO ACIDS IN PREGNANCY 1
}

\author{
By EVELYN B. WALLRAFF, EMILY C. BRODIE, AND ALICE L. BORDEN
}

(From the Department of Nutrition, University of Arizona, and Southwestern Clinic and Research Institute, Tucson, Arizona)

(Submitted for publication June 16, 1950; accepted, August 28, 1950)

\section{INTRODUCTION}

Increased urinary excretion of histidine during pregnancy is well known. In fact, it has received considerable attention as a possible chemical test for early pregnancy (1-4). Tyrosinuria in pregnancy has been reported by Lawrie (5). Because pregnancy often produces clinical remissions in rheumatoid arthritis, and because it has been reported that remissions produced with adrenocorticotrophic hormone and 17-hydroxy-11-dehydrocorticosterone result in increased excretion of histidine (6) and other amino acids ( 7 ), it was thought worthwhile to investigate the aminoaciduria of pregnancy. This paper reports the urinary excretion of 14 amino acids measured microbiologically. Urinary amino acid excretions of 12 normal pregnant women are compared with those of 12 normal non-pregnant women.

\section{EXPERIMENTAL}

Of the 12 women in the pregnancy group, one was in the first, three were in the second, and eight were in the third trimester of pregnancy. The average stage of pregnancy was 6.8 months. The non-pregnant women were apparently in good health and were of comparable age with the pregnancy group. Twenty-four hour urine specimens were collected under toluene. During this period, dietary records were taken. The urine was diluted to $2,000 \mathrm{ml}$. If the original volume was above $2,000 \mathrm{ml}$, no dilution was made. Approximately 200 to $300 \mathrm{ml}$. aliquots were stored at $-15^{\circ} \mathrm{C}$. until all urines were ready for analysis. When samples were taken from the deep freeze they were allowed to thaw at room temperature, and were thoroughly mixed before sampling.

For determination of "free" amino acids, $10 \mathrm{ml}$. of urine were neutralized to $\mathrm{pH} 6.9$ with $\mathrm{NaOH}$ or $\mathrm{HCl}$. The neutralized urine was then transferred quantitatively and diluted for assay. Dilutions ranged from 1:5 to 1:100 depending on the amino acid assayed. For determination of total amino acids other than tryptophan, $10 \mathrm{ml}$. of urine were pipetted into a $50 \mathrm{ml}$. beaker and 2 ml. of $3: 1$ concentrated $\mathrm{HCl}$ were added. The samples were then autoclaved at $250^{\circ} \mathrm{F}$. for five hours. After cooling, the $\mathrm{pH}$ was adjusted with $\mathrm{NaOH}$ to $\mathrm{pH}$ 6.9. The neutralized, hydrolyzed urine was then quantitatively

1 Supported in part by grants from the Fair Foundation and the United States Public Health Service. transferred to $50 \mathrm{ml}$. volumetric graduates, diluted to $\mathbf{5 0}$ $\mathrm{ml}$. and filtered. The filtrate (1:5 dilution of original urine) was then diluted for assay. Dilutions for determination of total amino acids ranged from $1: 10$ to $1: 100$. For determination of total tryptophan, the procedure was identical except that $2 \mathrm{ml}$. of saturated $\mathrm{NaOH}$ was substituted for the $\mathrm{HCl}$ and $50 \mathrm{mg}$. of cysteine hydrochloride was added to prevent loss of tryptophan. In calculating total tryptophan, it was assumed that total racemization had occurred.

An equal number of normal and pregnancy specimens were assayed in one series because of variations between series. Organism response is possibly an important cause of this variation. The assay procedure and media, with slight modifications, were those of Henderson and Snell (8). For glutamic acid assays, the modifications suggested by Brickson and his associates (9) were followed. For serine assays, a modification of the medium III of Sauberlich and Baumann (10) was used. All samples were assayed in duplicate at three levels of concentration. "Free" and total amino acids for each sample were assayed in the same series and calculated from the same standard curve. "Bound" values were obtained by subtracting the "free" value from the total. The test organisms were Leuconostoc mesenteroides $P-60$, Lactobacillus arabinosus $17-5$ and Streptococcus fecalis $R$.

\section{RESULTS AND DISCUSSION}

The data in Table I show that of the 14 "free" (microbiologically available without hydrolysis) amino acids assayed, seven are excreted in significantly ${ }^{2}$ higher amounts in the pregnancy group (11). These seven include histidine, tyrosine, arginine, phenylalanine, serine, threonine and tryptophan. Also, it is evident that aspartic acid and lysine closely approach a significant level ( $\mathrm{P}=$ 0.05 ) and warrant further investigation. By contrast, of the 13 "bound" amino acids studied only two, glutamic acid and tryptophan, are significantly higher in the pregnancy group. "Bound" serine closely approaches the significant level. Total histidine determinations were made, but because of apparent partial destruction of histidine in urine on acid hydrolysis, "bound" values were unobtainable. It is interesting to note that none of the amino acids studied is excreted in lower

$2 \mathrm{P}$ less than 0.05 . 
TABLE I

Urinary excretion of "free" and "bound" amino acids by 12 normal pregnant women as compared with 12 normal non-pregnant women

Reported as mg. per 24 hours

\begin{tabular}{|c|c|c|c|c|c|c|}
\hline \multirow[t]{2}{*}{ Amino acid } & \multicolumn{2}{|c|}{ Pregnancy } & \multicolumn{2}{|c|}{ Normal } & \multirow[t]{2}{*}{$\begin{array}{l}\text { Difference } \\
\text { of means }\end{array}$} & \multirow[t]{2}{*}{$\begin{array}{l}\text { Value } \\
\text { of " } \mathrm{t} \text { " }\end{array}$} \\
\hline & Range & Mean & Range & Mean & & \\
\hline $\begin{array}{l}\text { Free } \\
\text { Bound }\end{array}$ & $\begin{array}{r}4.2-11.4 \\
17.1-42.2\end{array}$ & $\begin{aligned} 8.0 \pm & 0.5^{*} \\
27.9 \pm & 2.3\end{aligned}$ & $\begin{array}{r}4.0-\quad 6.5 \\
18.2-28.6\end{array}$ & $\begin{aligned} 5.1 & \pm 0.7^{*} \\
23.8 & \pm 0.8\end{aligned}$ & $\begin{array}{l}2.9 \\
4.1\end{array}$ & $\begin{array}{l}3.30 \ddagger \\
1.67\end{array}$ \\
\hline $\begin{array}{l}\text { Free } \\
\text { Bound } \\
\text { Glutamic Acid }\end{array}$ & $\begin{array}{r}1.7-11.5 \\
56.2-280.2\end{array}$ & $\begin{array}{r}6.9 \pm 0.9 \\
133.5 \pm 21.9\end{array}$ & $\begin{array}{r}0.0-9.5 \\
44.6-211.0\end{array}$ & $\begin{array}{r}4.7 \pm 0.7 \\
107.7 \pm 14.9\end{array}$ & $\begin{array}{r}2.2 \\
25.8\end{array}$ & $\begin{array}{l}1.93 \\
0.98\end{array}$ \\
\hline $\begin{array}{l}\text { Gluamic Acie } \\
\text { Free }\end{array}$ & Values too $\mathrm{sr}$ & to be measured & ccurately & & & \\
\hline$\underset{\text { Histidine }}{\text { Bound }}$ & $76.0-648.5$ & $253.2 \pm 43.0$ & $66.6-218.0$ & $127.7 \pm 13.0$ & 125.5 & $2.79 \ddagger$ \\
\hline $\begin{array}{c}\text { Free } \\
\text { Isoleucine }\end{array}$ & $218-720$ & $371 \pm 44$ & $49-158$ & $112 \pm 11$ & 259 & $5.76 \ddagger$ \\
\hline $\begin{array}{l}\text { Free } \\
\text { Bound } \\
\text { Leucine }\end{array}$ & $\begin{array}{r}1.9-4.5 \\
4.0-14.2\end{array}$ & $\begin{array}{l}2.9 \pm 0.3 \\
9.3 \pm 0.9\end{array}$ & $\begin{array}{l}0.6-\quad 4.7 \\
0.0-26.1\end{array}$ & $\begin{array}{r}2.6 \pm 0.4 \\
11.5 \pm 2.9\end{array}$ & $\begin{array}{l}0.3 \\
2.2\end{array}$ & $\begin{array}{l}0.64 \\
0.73\end{array}$ \\
\hline $\begin{array}{c}\text { Free } \\
\text { Bound } \\
\text { Lysine }\end{array}$ & $\begin{array}{r}8.6-25.6 \\
14.8-89.2\end{array}$ & $\begin{array}{l}18.5 \pm 1.6 \\
49.2 \pm 7.2\end{array}$ & $\begin{array}{r}8.0-28.2 \\
24.0-82.6\end{array}$ & $\begin{array}{l}18.5 \pm 1.6 \\
43.8 \pm 4.6\end{array}$ & $\begin{array}{l}0.0 \\
5.4\end{array}$ & $\begin{array}{l}0.00 \\
0.63\end{array}$ \\
\hline $\begin{array}{l}\text { Free } \\
\text { Bound } \\
\text { Methionine }\end{array}$ & $\begin{array}{r}11.7-52.3 \\
0.0-51.6\end{array}$ & $\begin{array}{l}25.3 \pm 3.6 \\
15.3 \pm 4.5\end{array}$ & $\begin{array}{l}6.4-36.1 \\
5.2-29.9\end{array}$ & $\begin{array}{l}17.1 \pm 2.3 \\
16.2 \pm 2.2\end{array}$ & $\begin{array}{l}8.2 \\
0.9\end{array}$ & $\begin{array}{l}1.94 \\
0.18\end{array}$ \\
\hline $\begin{array}{l}\text { Free } \\
\text { Bound } \\
\text { Phenylalanine }\end{array}$ & $\begin{array}{l}3.8-14.9 \\
0.0-13.2\end{array}$ & $\begin{array}{l}7.1 \pm 1.0 \\
8.1 \pm 1.3\end{array}$ & $\begin{array}{lr}2.6- & 8.5 \\
0.0- & 12.2\end{array}$ & $\begin{array}{l}5.6 \pm 0.4 \\
5.0 \pm 1.9\end{array}$ & $\begin{array}{l}1.5 \\
3.1\end{array}$ & $\begin{array}{l}1.44 \\
1.38\end{array}$ \\
\hline $\begin{array}{l}\text { Free } \\
\text { Bound } \\
\text { Serine }\end{array}$ & $\begin{array}{l}7.2-26.4 \\
0.0-21.7\end{array}$ & $\begin{array}{r}13.9 \pm 1.7 \\
8.5 \pm 1.8\end{array}$ & $\begin{array}{l}3.2-13.1 \\
0.0-19.8\end{array}$ & $\begin{array}{l}8.5 \pm 0.8 \\
5.9 \pm 2.2\end{array}$ & $\begin{array}{l}5.4 \\
2.6\end{array}$ & $\begin{array}{l}2.95 \ddagger \\
0.91\end{array}$ \\
\hline $\begin{array}{c}\text { Free } \\
\text { Bound } \\
\text { Threonine }\end{array}$ & $\begin{array}{r}27.4-198.0 \\
9.0-54.0\end{array}$ & $\begin{array}{l}77.9 \pm 16.5 \\
28.3 \pm 4.2\end{array}$ & $\begin{array}{r}12.0-64.4 \\
0.0-39.4\end{array}$ & $\begin{array}{l}26.5 \pm 4.3 \\
17.3 \pm 3.4\end{array}$ & $\begin{array}{l}51.4 \\
11.0\end{array}$ & $\begin{array}{l}3.01 \\
2.04 \ddagger\end{array}$ \\
\hline $\begin{array}{c}\text { Free } \\
\text { Bound } \\
\text { Tryptophan }\end{array}$ & $\begin{array}{r}26.8-282.6 \\
0.0-45.8\end{array}$ & $\begin{array}{r}107.5 \pm 24.4 \\
13.1 \pm 5.2\end{array}$ & $\begin{array}{l}6.0-28.0 \\
2.4-27.4\end{array}$ & $\begin{array}{l}13.3 \pm 2.1 \\
11.8 \pm 2.4\end{array}$ & $\begin{array}{r}94.2 \\
1.3\end{array}$ & $\begin{array}{l}3.85 \ddagger \\
0.23\end{array}$ \\
\hline $\begin{array}{c}\text { Free } \\
\text { Bound } \\
\text { Tyrosine }\end{array}$ & $\begin{array}{r}12.8-64.0 \\
7.2-31.2\end{array}$ & $\begin{array}{l}28.3 \pm 4.9 \\
20.2 \pm 2.2\end{array}$ & $\begin{array}{l}5.8-18.4 \\
0.0-23.2\end{array}$ & $\begin{array}{r}10.4 \pm 0.9 \\
7.5 \pm 2.4\end{array}$ & $\begin{array}{l}17.9 \\
12.7\end{array}$ & $\begin{array}{l}3.60 \ddagger \\
3.88 \ddagger\end{array}$ \\
\hline $\begin{array}{c}\text { Free } \\
\text { Bound } \\
\text { Valine }\end{array}$ & $\begin{array}{r}9.6-86.6 \\
25.0-62.2\end{array}$ & $\begin{array}{l}30.6 \pm 6.7 \\
43.3 \pm 3.6\end{array}$ & $\begin{array}{r}5.8-20.6 \\
15.0-57.2\end{array}$ & $\begin{array}{l}13.2 \pm 1.2 \\
36.8 \pm 3.9\end{array}$ & $\begin{array}{r}17.4 \\
6.5\end{array}$ & $\begin{array}{l}2.54 \dagger \\
1.23\end{array}$ \\
\hline $\begin{array}{l}\text { Free } \\
\text { Bound }\end{array}$ & $\begin{array}{l}1.2-11.8 \\
3.9-43.2\end{array}$ & $\begin{array}{r}4.8 \pm 0.9 \\
15.5 \pm 3.4\end{array}$ & $\begin{array}{l}0.6-7.4 \\
0.2-26.3\end{array}$ & $\begin{array}{l}3.3 \pm 0.6 \\
8.8 \pm 2.5\end{array}$ & $\begin{array}{l}1.5 \\
6.7\end{array}$ & $\begin{array}{l}1.32 \\
1.43\end{array}$ \\
\hline
\end{tabular}

* Standard error of the mean

$\dagger$ Significant ( $P$ less than 0.05$)$

$\ddagger$ Highly significant ( $\mathrm{P}$ less than $\mathbf{0 . 0 1}$ )

amounts in pregnancy. This applies to both "free" and "bound" forms.

In general, there was a greater variation between individuals in the pregnancy group than in the normal. There is overlapping of values in the two groups for all the amino acids except histidine. All normal women excreted $214 \mathrm{mg}$. of histidine or less, while all pregnant women excreted $294 \mathrm{mg}$. of histidine or more. From our data, it appears that there was no correlation between month of pregnancy and excretion of higher amounts of amino acids. However, our subjects were too few in number in the first and second trimester to show such a correlation adequately if it did exist.
Protein, carbohydrate, fat, and caloric intake were estimated from dietary records taken during the period of collection of specimens (12). Table II indicates the range and mean of estimated intake for the two groups of women. In order to test the influence of estimated protein intake on excretion of specific amino acids, rank correlation coefficients were computed for those amino acids found to be excreted in significantly higher amounts (Table III). In the non-pregnant group there is a significant correlation ${ }^{3}$ between protein intake and excretion of free histidine and free arginine. In pregnant women, however, there is ${ }^{3} \mathrm{P}$ less than 0.05 . 
TABLE II

Range and mean of estimated intake taken from dietary records*

\begin{tabular}{|c|c|c|c|c|}
\hline & Protein & $\begin{array}{l}\text { Carbohy- } \\
\text { drate }\end{array}$ & Fat & Calories \\
\hline $\begin{array}{c}\text { Pregnant } \\
\text { Range } \\
\text { Mean }\end{array}$ & $\begin{array}{c}\text { gm. per } \\
24 \mathrm{hr} . \\
36.4-124.6 \\
81.1\end{array}$ & $\begin{array}{c}\text { gm. per } \\
24 \text { hr. } \\
125.3-302.2 \\
212.4\end{array}$ & $\begin{array}{c}\text { gm. per } \\
24 \mathrm{hr} . \\
32.6-151.0 \\
89.6\end{array}$ & $\begin{array}{c}\text { per } 24 \mathrm{hr} . \\
1,063-2,740 \\
1,926\end{array}$ \\
\hline $\begin{array}{l}\text { Non-Pregnant } \\
\text { Range } \\
\text { Mean }\end{array}$ & $\begin{array}{c}50.1-160.0 \\
88.8\end{array}$ & $\begin{array}{c}118.8-369.1 \\
237.1\end{array}$ & $\begin{array}{c}42.8-216.0 \\
107.4\end{array}$ & $\begin{array}{c}1,345-3,667 \\
2,272\end{array}$ \\
\hline
\end{tabular}

* Pregnant women were on dietary regulation depending on weight gain.

no correlation between protein intake and any of the amino acids excreted in higher amounts. We interpret this as evidence to support the view that the state of pregnancy rather than diet is the cause of differences found.

\section{TABLE III}

\begin{tabular}{|c|c|c|}
\hline \multicolumn{3}{|c|}{$\begin{array}{c}\text { Rank correlations for protein intake versus } \\
\text { amino acid excretion }\end{array}$} \\
\hline Amino acid & $\begin{array}{c}\text { Non-pregnant } \\
\text { women }\end{array}$ & $\underset{\text { women }}{\text { Pregnant }}$ \\
\hline $\begin{array}{l}\text { Histidine (free) } \\
\text { Threonine (free) } \\
\text { Tyrosine (free) } \\
\text { Serine (free) } \\
\text { Arginine (free) } \\
\text { Phenylalanine (free) } \\
\text { Tryptophan (free) } \\
\text { Tryptophan (bound) } \\
\text { Glutamic acid (bound) }\end{array}$ & $\begin{array}{l}0.745^{*} \\
0.479 \\
0.091 \\
0.291 \\
0.685^{*} \\
0.430 \\
0.624 \\
-0.236 \\
0.188\end{array}$ & $\begin{array}{r}0.287 \\
-0.049 \\
0.343 \\
0.063 \\
-0.070 \\
0.280 \\
-0.021 \\
0.182 \\
0.273\end{array}$ \\
\hline Significant. & & \\
\hline
\end{tabular}

Whether these differences are due to changes in renal function as has been suggested for histidine by Page (1), are indirectly due to higher production of adrenal cortical hormones or whether they are due to some other metabolic change associated with pregnancy, we are not prepared to say at the present time.

\section{SUMMARY}

Using a modification of the Henderson and Snell method for microbiological assay, both "free" and "bound" amino acids were determined in 24 hour urine specimens from 12 normal pregnant and 12 normal non-pregnant women.

1. Seven "free" amino acids were found to be excreted in significantly higher amounts in the pregnancy group: histidine, tyrosine, serine, arginine, phenylalanine, threonine, and tryptophan.

2. "Bound" glutamic acid, liberated by acid hy- drolysis was excreted in significantly higher amounts in the pregnancy group.

3. "Bound" tryptophan, which was liberated by alkaline hydrolysis, was excreted in significantly higher amounts in pregnancy.

4. None of the 14 amino acids assayed both in "free" and "bound" form was significantly lower in the urine from pregnant women.

\section{ACKNOWLEDGMENTS}

The authors acknowledge with thanks the cooperation of Mrs. Carl Appelin and Dr. Hollis H. Brainard.

\section{BIBLIOGRAPHY}

1. Page, E. W., The excretion rates of histidine in pregnant and nonpregnant women. West. J. Surg., 1943, 51, 482.

2. Racker, E., Histidine detection and estimation in urine. Biochem. J., 1940, 34, 89.

3. Langley, W. D., Urinary histidine; determination of histidine in urine. Histidine in normal and in pregnancy urines. J. Biol. Chem., 1941, 137, 255.

4. Chattaway, F. W., The estimation of histidine in urine and its excretion by normal and pregnant women. Biochem. J., 1947, 41, 226.

5. Lawrie, N. R., The excretion of $1(-)$-tyrosine in urine. Biochem. J., 1947, 41, 41.

6. Stephens, C. A. L., Jr., Wallraff, E. B., Borden, A. L., Brodie, E. C., Holbrook, W. P., Hill, D. F., Kent, L. J., and Kemmerer, A. R., Apparent free histidine plasma and urine values in rheumatoid arthritis treated with cortisone and ACTH. Proc. Soc. Exper. Biol. \& Med., 1950, 74, 275.

7. Holbrook, W. P., Hill, D. F., Stephens, A. L., Jr., Kent, L. J., and Borden, A., The effect of ACTH on amino acid metabolism in rheumatoid arthritis, in Proceedings of the First Clinical ACTH Conference. Blakiston Co., Philadelphia, 1950, p. 386 .

8. Henderson, L. M., and Snell, E. E., A uniform medium for determination of amino acids with various microorganisms. J. Biol. Chem., 1948, 172, 15.

9. Brickson, W. L., Henderson, L. M., Solhjell, I., and Elvehjem, C. A., Antagonism of amino acids in the growth of lactic acid bacteria. J. Biol. Chem., 1948, 176, 517.

10. Sauberlich, H. E., and Baumann, C. A., The effect of dietary protein upon amino acid excretion by rats and mice. J. Biol. Chem., 1946, 166, 417.

11. Snedecor, G. W., Statistical Methods Applied to Experiments in Agriculture and Biology. Collegiate Press, Ames, Iowa, 1937, p. 69.

12. Watt, B. K., and Merrill, A. L., Composition of Foods-Raw, Processed, Prepared. Agriculture Handbook No. 8, U. S. Dept. of Agriculture, Washington, D. C., 1950, p. 92. 